\title{
RAS-Related GTP-Binding Protein A
}

National Cancer Institute

\section{Source}

National Cancer Institute. RAS-Related GTP-Binding Protein A. NCI Thesaurus. Code C29758.

Ras-related GTP-binding protein A (313 aa, $237 \mathrm{kDa}$ ) is encoded by the human RRAGA gene. This protein plays a role in the cellular response to amino acid starvation. 